\title{
The Role of Paraphrasing in Writing Research Papers
}

\author{
Pungky Ramadhani \\ Institut Pesantren KH. Abdul Chalim \\ (pungkyramadhani@gmail.com)
}

Approved: $2020-01-28$

Key Words:

Plagiarism

Paraphrase

Writing a Research

Paper

\section{ABSTRACT}

Almost all people in this world have experienced in writing a research paper. Nevertheless, there are only some people who understand how to write appropriately. Plagiarism still becomes a big problem among the writers. This happens because they often get difficulty in integrating sources into the text. As the writers, they should know how to overcome that problem. The existence of paraphrasing can be a way to avoid the plagiarism. The writers can paraphrase a direct quote of someone using their own words. This can be a great way to increase the quality of research papers.

\section{Introduction}

Writing a research paper is an activity where the writers try to develop their ideas from the reliable sources. It is such an important skill to learn, especially for the academic writing. Research paper is considered as long pieces of written work. To write a research paper, we must conduct some research. We also need to collect many sources, including books, scientific journal, article, and so forth. Through this activity, we can acquaint the protocol of making correct citations to sources consulted, and give knowledge about how to forge a mishmash of researched opinions into a single, coherent view point (Winkler and Jo Ray McCuen-Matherell). Writing research paper involves integrating the sources

Pungky Ramadhani

The Role of Paraphrasing in Writing Research Papers
(117)

$$
\text { http://e-journal.ikhac.ac.id/index.php/alsuna }
$$
https://doi.org/10.31538/alsuna 
of information. Then they are written in the footnote of the pages. Therefore, the readers can understand where the information is come from and judge whether it is reliable.

Some people often find difficulties in integrating sources (Zuana). Furthermore, it is the crucial activity in writing research paper. As the writers, they should be able to integrate the sources to support the point in the paper. In fact, to work with source text is one of the challenging academic activities for the writers. They have to receive considerable attention in academic writing courses to avoid plagiarism when they deal with source text material (Diane Pecorari). Plagiarism means using someone's work and claiming it as our own. In this case, the writers should avoid the tendency of plagiarism in integrating the sources into the paper. It is such a difficult work, moreover if the writers do not have the ability to integrate the sources properly. The writer should use a certain way in order to avoid the problems. In this paper, I will demonstrate that paraphrasing can be the way to integrate and rewrite source texts.

Paraphrasing is an important part of writing a paper. In paraphrasing, the writers try to rewrite a direct quote from a text such as books or journals into their own words. This does not mean changing a few words around. It means taking the authors ideas, summarizing them into the writers' own words and then using them (Kusrini). In a good paraphrase, the original sentences and vocabulary of the source text may not be written in the paper. The writers cannot merely substitute synonyms of the sentences and vocabulary, and then leave them without change the arrangement of the text (Brenda Spatt). Writing a good paraphrase, automatically, requires the writers to consider both the precise use of words and the sense of the whole statements. Actually, paraphrase is a part of a process of understanding and responding to a specific written passage. This means that the writers should deal with the people' ideas to get the whole explanation of the source text.

Pungky Ramadhani

The Role of Paraphrasing in Writing Research Papers
(118)

http://e-journal.ikhac.ac.id/index.php/alsuna https://doi.org/10.31538/alsuna 
By examining paraphrasing, I will demonstrate that paraphrasing can be a way to help the writers in integrating the source. Paraphrasing can help the writers to get a detail understanding of the sources text (Bazerman). This paper will define what writing research paper is, describe what paraphrasing is, explain the procedure of how to paraphrase, and argue for the role of paraphrasing in writing research paper.

\section{Writing Research Paper}

Writing a research paper, actually, forces the writers to find out information about a subject area, and bring on the opinions and ideas toward their paper (Carol Ellison). The research paper is a formal work that must abide by the rules of scholarly writing. Writing a research paper involves all the steps for writing an essay. It starts from introduction to conclusion. It has also some additions in each part of the paper.

Writing the research paper is such a practice of imagination, logic and common sense (Carol Ellison). Research paper begins with writing an article. It may be specific. It may be general. Normally, first, the writers should determine the topic. After that they have to point the direction of the research that they want to take. The writers should expand the topic of the research in order to get the description of their paper. They should also have the direction to achieve a success in writing. The writers need to know what they want to expect, how to prepare and also explain it. During the writing process, the writers will have a lot of trial and error to get there.

According to Winkler \& Jo Ray McCuen-Matherell (2008), generally there are seven distinct steps in the process of writing research paper:

a. The writers must select a topic that is complex enough to be researched from a variety of sources but narrow enough to be covered in 10 or so pages. In this stage,

Pungky Ramadhani

The Role of Paraphrasing in Writing Research Papers
(119)

http://e-journal.ikhac.ac.id/index.php/alsuna https://doi.org/10.31538/alsuna 
the writers may provide two or more acceptable topics, and then consult them to their instructor to determine which topic that will be approved.

b. The writers must do the exploratory scanning and reading of sources based on the topic. It is important for the writers to read some sources based on the topic of their research. Simply, it is because the writers need to build their ideas to develop the research paper. The writers can find the sources from the book, scientific journal, article and so forth.

c. The writers must gather information on your topic and assemble it into some usable sequence. Making an outline is such an important activity when the writers want to write a paper. It used to narrow the perspective of the writers based on the topic. So, the writers can determine what they want to do with their paper. They can start to think about the instruments that they want to conduct. Thesis statement is also created in this stage.

d. The writers must draft a thesis statement expressing the major idea behind the paper. In this stage, the writers are asked to write draft based on the thesis statement of their research paper. They can show what the direction of major of the idea in the research. Thus, the writers can decide what they want to do with their own topic and thesis statement.

e. The writers must outline the major parts of the paper. An outline should be on the list of major parts of a certain point in the paper. So, the writers just take several points which are important that will be elaborated more in the paper.

f. The writers must write a rough draft of the paper arguing, proving, or supporting your thesis with information uncovered by the research. You must acknowledge all borrowed ideas, data, and opinions. The writers should make a rough draft about the content of the paper. So here, the outline that they have made is

Pungky Ramadhani

The Role of Paraphrasing in Writing Research Papers
(120)

$$
\text { http://e-journal.ikhac.ac.id/index.php/alsuna }
$$
https://doi.org/10.31538/alsuna 
elaborated in this stage. The writers must collect some sources that they have had to support their paper. They can do some kinds of ways to take the statement from the sources.

g. The writers must prepare a reference listing all sources used in the paper and they must write the final draft. All works should be done in this stage. The writers should finish their research paper complete with the references.

\section{Definition of Paraphrasing}

Some people say that paraphrasing is similar to summarizing. Pamela J. Sharpe (2006) said that when the writers take the content into one's own words in paraphrasing is often considered similar as summarizing. In fact, paraphrasing is different from summarizing. It is much easier than summarizing. To summarize something, the writers are supposed to make the passage shorter. This means that the writers should only take the important points of the passage, then import them to be a new passage. The points are general statement of the passage, topic sentence, removing the redundancy of the sentence, and certainly removing the unimportant information of the passage (Brenda Spatt).

Paraphrasing, actually, does not means that the writers should make the difference between important and unimportant points in the passage (Brenda Spatt). Nevertheless, the writers should know the main point of the passage in order to produce a good paraphrase. This is similar when the writers want to summarize something. They will try to understand the passage, take the main points of the passage to produce a good summary. Besides summarizing is more formal than paraphrasing. In order to master the ability of summarizing, the writers need to practice how to do it well. On the other hand, in paraphrasing, students may be able to paraphrase long before they acquire the ability

Pungky Ramadhani

The Role of Paraphrasing in Writing Research Papers
(121)

$$
\text { http://e-journal.ikhac.ac.id/index.php/alsuna }
$$
https://doi.org/10.31538/alsuna 
to summarize. By examining this phenomenon, we can say that paraphrasing may be seen as a basic to learn how to summarize properly.

Paraphrasing is also not the same with retelling something. In retelling, readers are expected to use the words of the author when they explain the passage (Brenda Spatt). In fact, the readers are interested to use their own words. This means that they tend to use the phrasing of the original text. It is actually good for them. The readers can be able to retell without taking the content of the passages, yet they must deal with the content if they do paraphrasing.

Paraphrasing, indirectly, encourages the writers to engage their prior knowledge to access what is already known about the topic. It also expects the writers to use words which belong to parts of the writers' knowledge. This activity can help the writers to construct retrieval cues that enable to integrate what is previously known with what is being read. It is considered as the important part to comprehend a passage.

In paraphrasing, the writers should pay attention on two points. They are the meaning of words and the relationship between words as they are used in context (Bazerman). The writers must be responsible to the content of the context. They have to make sure that they will take the original context. This means that they are will not add anything new and misrepresent the original content.

\section{The Procedure of How to Paraphrase}

In this paper, there is also procedure how to paraphrase correctly. Writing a good paraphrase requires the writers to pay attention on the choice of words and the sense of the whole statements. To consider the meaning of the text, the writers who want to paraphrase a certain statement must know how to take the statement then put them into

Pungky Ramadhani

The Role of Paraphrasing in Writing Research Papers
(122)

http://e-journal.ikhac.ac.id/index.php/alsuna https://doi.org/10.31538/alsuna 
the written work (Brenda Spatt). Understanding the point of the statement in a text will need an effort from the writers to achieve success on paraphrasing.

The writers should follow these several steps to paraphrase sentences/paragraphs effectively. They should pay attention on each step in order to create a good paraphrase. According to Brenda Spatt (2011), when the writers intend to paraphrase something, they need to understand the ideas and concepts of the original text. It is important because by understanding the ideas of original text, they can express the idea and write in their own words. The writers are not allowed to copy the complete sentence, they just write a few words as possible.

Second, the writers should write the bibliographical details of the sources. It is used to write the reference in their paper. Whenever they cite a statement, they should write the sources. It can also avoid the plagiarism.

The next step is developing the position and viewpoints. The writers should make outline before they make a paraphrase. The material of paraphrasing should fully into the writers' own style, words, and grammar. Underlining some words that can be substituted with a synonym is also needed in paraphrasing.

The fourth step is putting the original text away. In other words, the writers do not allow to put the original text into the written work. The writers can start to paraphrase the statements using their notes. In the process of paraphrasing, certainly, the writers should rewrite the point of a certain statement. Nevertheless, they are not allowed to merely substitute the words. They must also change the structure of the original text. Yet, they should try to keep the meaning and the sense of the statements taken from the original text. Then, the writers should write the sentence using their own words and change the structure of the sentences without changing the meaning from the original text.

Pungky Ramadhani

The Role of Paraphrasing in Writing Research Papers
(123)

http://e-journal.ikhac.ac.id/index.php/alsuna https://doi.org/10.31538/alsuna 
The last, the writers should compare their paraphrase with the original text to make sure that it expresses the same ideas and sense that are stated in the original text.

\section{Research Method}

This research This research is considered as library research. This means that libraries become the main repositories of the research materials (Abbott). The researcher tried to collect some books and journals to get the whole explanation related to the role of paraphrasing in writing research paper.

\section{Discussion}

Effective paraphrasing is considered as an important part of academic skill (Bailey). This is used to avoid the risk of plagiarism in a research paper. To paraphrase a statement, automatically, the writers are required to understand about the source text. Some source statements are taken for the sake of their precise or elegant style. Nevertheless, many source statements that the writers use in research paper are written in ordinary language. As the writers, they should have an ability to produce a good paraphrasing (Bazerman).

Paraphrasing, actually, helps the writers to get an understanding of the source text. According to Bazerman (2010), there are two reasons for using paraphrase in research paper. First, paraphrasing is able to show the information whenever the writers need to use a direct quotation. There are many source texts which do not have adequate authority to justify the words of the writers. Second, paraphrasing is used to give the readers an accurate and comprehensive ideas taken from a source idea that the writers' intend to explain in the research paper.

Pungky Ramadhani

The Role of Paraphrasing in Writing Research Papers
(124)

http://e-journal.ikhac.ac.id/index.php/alsuna https://doi.org/10.31538/alsuna 
Paraphrase, indirectly, requires the writers to improve their understanding of a complex passage. This means that through paraphrase the writers learn about how to comprehend a text efficiently. Winkler \& Jo Ray McCuen-Matherell (2008) stated that the writers can get more knowledge during the process of paraphrase. When they get difficulty to understand a source text, they will try to take notes by using their own words. So that they gradually understand about the main point of the source text. Paraphrasing also helps the writers working with the ideas that may at first seem beyond their comprehension.

Here are the examples of paraphrase;

\begin{tabular}{|c|c|c|c|}
\hline NOTE & QUOTE & PARAPHRASE & COMMENT \\
\hline Harmer (2001:215) & 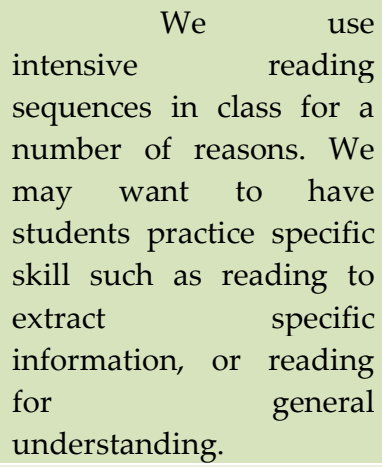 & $\begin{array}{l}\text { The purpose of } \\
\text { intensive reading is to train } \\
\text { the students' reading skill to } \\
\text { get the understanding of } \\
\text { reading in general. }\end{array}$ & $\begin{array}{l}\text { I will apply } \\
\text { intensive reading to } \\
\text { students to increase their } \\
\text { reading skill, therefore } \\
\text { students can gain } \\
\text { understanding without } \\
\text { translating each word in } \\
\text { the text. So, they do not } \\
\text { need to check the difficult } \\
\text { word in the dictionary. }\end{array}$ \\
\hline Harmer (2001:221) & $\begin{array}{lcr} & \text { Reading } \\
\text { often a prelude to a } \\
\text { speaking } & \text { or writing } \\
\text { activity. } & \end{array}$ & $\begin{array}{l}\text { Speaking and } \\
\text { writing activity is an } \\
\text { introduction in reading }\end{array}$ & $\begin{array}{l}\text { Teachers often } \\
\text { use reading as an } \\
\text { introduction to encourage } \\
\text { students' speaking and } \\
\text { activity }\end{array}$ \\
\hline Harmer (2001:217) & $\begin{array}{l}\text { In Intensive } \\
\text { reading, students may } \\
\text { start by identifying the } \\
\text { topic of a text before } \\
\text { scanning it quickly to } \\
\text { recover specific } \\
\text { information. }\end{array}$ & $\begin{array}{l}\text { In getting the } \\
\text { information, students } \\
\text { should identify the topic } \\
\text { before scanning the text. }\end{array}$ & $\begin{array}{l}\text { Teachers may } \\
\text { start reading activity by } \\
\text { scanning the text then ask } \\
\text { students to identify the } \\
\text { topic. }\end{array}$ \\
\hline
\end{tabular}

The table above are the example of notes how the writers paraphrase statements. Taking notes during the process of paraphrase is such as an important thing to produce a good paraphrasing.

Pungky Ramadhani

The Role of Paraphrasing in Writing Research Papers
(125)

http://e-journal.ikhac.ac.id/index.php/alsuna https://doi.org/10.31538/alsuna 
Here is an example of paraphrase of a short passage. This example taken from the book from Bailey (2011);

There has been much debate about the reasons for the industrial revolution happening in eighteenth-century Britain, rather than in France or Germany.

could be paraphrased;

Why the industrial revolution occurred in Britain in the eighteenth century, instead of on the continent, has been the subject of considerable discussion.

From the example above, we can see the distinction between the original passage and the result of paraphrase. It is obvious that Bailey (2011) only takes the main point of the original text then rewrites them by using her own words.

Subsequently, by examining the examples of paraphrase above. We can learn how to make a good paraphrase. This is very important in a research paper to make it valid.

\section{Conclusion}

Writing research paper is considered as a challenging activity. The writers have to deal with the ability in writing. It is not such an easy work. They should collect many sources to get the ideas before they continue to the next step in writing research paper. Not only for getting the ideas, but also the writers should be able to integrate the sources to support the point of the paper. It needs a kind of ability to put some statements from the sources in the paper.

Paraphrasing is one of the ways to integrate the sources. The writers can paraphrase based on the statement or the author's opinion of the passage. Simply, the

Pungky Ramadhani

The Role of Paraphrasing in Writing Research Papers
(126)

$$
\text { http://e-journal.ikhac.ac.id/index.php/alsuna }
$$
https://doi.org/10.31538/alsuna 
writers have to read first about the statement that they want to paraphrase then rewrite them by using their own words. This activity can also become a way to avoid the plagiarism.

By examining the explanations above, I have shown that the role of paraphrasing in writing research paper is very crucial. For some people, comprehending the passage is not an easy work. Not all sources are written in simple passage. By using paraphrasing, the writers can improve their comprehension in complex passage because they can rewrite the statement with their own words. It can also help them in integrating the sources.

\section{Bibliography}

Abbott, Andrew. Library Research and Its Infrastructure in the Twentieth Century Windsor Lecture University of Illinois. 2008, pp. 1-27.

Bailey, Stephen. “Academic Writing: A Handbook for International Students, Third Edition." Journal of Chemical Information and Modeling, vol. 53, no. 9, 2011, doi:10.1017/CBO9781107415324.004.

Bazerman, Charles. The Informed Writer: Using Sources in the Disciplines 5th Edition. 2010.

Brenda Spatt. “Writing from Sources Eight Edition." Bedford/St. Martin's All, 2011.

Carol Ellison. "McGraw-Hill's Concise Guide to Writing Research Papers." The McGrawHill Companies, 2010.

Diane Pecorari. "Academic Writing and Plagiarism : A Linguistic Analysis." Continuum, 2008, doi:10.5040/9781474211727.

Kusrini, Nurul Azizah Ria. “Scientific Approach: Model-Based Inquiry in Teaching Narrative." ALSUNA: Journal of Arabic and English Language, vol. 1, no. 1, 2018, pp.

Pungky Ramadhani

The Role of Paraphrasing in Writing Research Papers
(127)

$$
\text { http://e-journal.ikhac.ac.id/index.php/alsuna }
$$
https://doi.org/10.31538/alsuna 
17-25, doi:10.31538/alsuna.v1i1.99.

Pamela J. Sharpe. TOEFL IBT Internet-Based Test 12th Edition. Barron's Educational Series, Inc., 2006.

Winkler, Anthony C., and Jo Ray McCuen-Matherell. "Writing The Research Paper Seventh Edition." Wadsworth, Cengage Learning, 2008, doi:10.1017/CBO9781107415324.004.

Zuana, Muhammad Mujtaba Mitra. “Digital Storytelling: An Attractive Media to Teach Narrative Text in Speaking Class." ALSUNA: JOURNAL OF ARABIC AND ENGLISH LANGUAGE, vol. 1, no. 1, 2018, pp. 26-39.

Pungky Ramadhani

The Role of Paraphrasing in Writing Research Papers
(128)

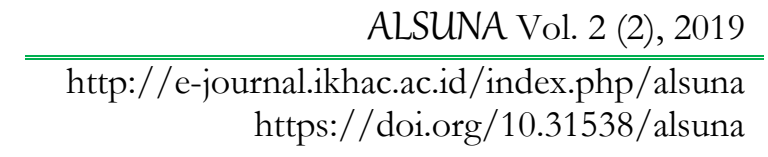

